\title{
Zombies in the German-Speaking Space. Review of the Collective Monograph "The Undead - Zombie Film Theory" Edited by M. Fürst, F. Krautkrämer and S. Wiemer
}

\section{Elina A. Sarakaeva}

Hainan Professional College of Economics and Business. Haikou, China

E-mail: 2689655292[at]qq.com

\section{Abstract}

This article reviews a collection of scholarly works edited by Michael Fürst, Florian Krautkrämer, and Serjoscha Wiemer "The Undead - Zombie Film Theory" (original title "Untot - Zombie Film Theorie"), Munich, Belleville Publishers, 2010, 301 pages, ISBN 978-3-933510-55-6. The reviewer lists the main ideas discussed by the researchers who have contributed to the monograph, briefly summarizes the content and evaluates the scientific significance of the analyzed edition. Three representative essays of the monograph (by W. Fuhrmann, A. Grilli and M. Benecke) receive a closer inspection, as they demonstrate the scope of ideas and methodological approach characteristic of the volume.

\section{Keywords}

Zombie; Cultural Studies; Art Criticism; Film Studies; Zombie Theory; Cinematic Landscape; Queer Theory; Mark Benecke 


\section{Зомби в немецкоязычном пространстве. Рецензия на коллективную монографию под редакцией М. Фюрста, Ф. Крауткамэра и С. Вимера «Немёртвые - теория зомби в кинематографе»}

\section{Саракаева Элина Алиевна}

Хайнаньский институт экономики и бизнеса. Хайкоу, Китай. E-mail: 2689655292[at]qq.com

\section{Аннотация}

В статье приводится рецензия на сборник научных работ под редакцией Михаэля Фюрста, Флориана Крауткрэмера и Серёжи Вимера «Немертвые - теория зомби в кинематографе» (название в подлиннике "Untot - Zombie Film Theorie"), Мюнхен, Издательство Бельвиль, 2010, 301 стр., ISBN 978-3-933510-55-6. Рецензент перечисляет основные идеи, обсуждаемые авторами на страницах монографии, кратко резюмирует контент и делает заключение о научной значимости анализируемого издания. Три статьи из монографии (за авторством В. Фурманна, А. Грилли и М. Бенеке) рассмотрены более подробно, поскольку они отражают масштаб идей и методологический подход, характерные для данного издания.

\section{Ключевые слова}

зомби; культурология; искусствоведение; киноведение; теория зомби; кинематографический ландшафт; квир-теория; Марк Бенеке

Это произведение доступно по лицензии Creative Commons «Attribution» («Атрибуция») 4.0 Всемирная 
Zombies seem to have won the public again. New movies, TV-shows, books, comics, computer games and cartoons about zombies appear every month, every year, almost every day. Zombies come from America, Great Britain, Northern Europe, Eastern Europe, Japan, Korea etc. They are funny and dreadful. They move slowly or run like wind. They wear shagged rags or they wear tuxedos or even Nazi uniform. There is a difference from the previous wave of zombie franchises, too unlike the early voodoo zombies or natural anomaly zombies, the undead are now more often the result of biological-medical experiments and the unscrupulousness of global corporations. They are carriers of viruses or they bring war and terror into the isolated crystal palaces of financial metropolises.

The reviewed book deals mostly with zombies in cinema. It is a first ever collection of scholarly research on the topic of zombie by German authors, edited by Michael Fürst, Florian Krautkrämer, and Serjoscha Wiemer and published in 2010 in München. In the preface the book proudly underlines the fact of being the first of its kind, compiling "for the first time ever research contributions from the Germanspeaking world" (Fürst, Krautkrämer \& Wiemer, 2010, p.10).

The book has three main chapters with about 280 pure text pages and 80 colored illustrations. Quoting the promotion text issued by Belleville Publishers, the book is about "...... the theory and history of the zombie film. From "White Zombie" to "Resident Evil", from Jacques Tourneur to George Romero to Bruce LaBruce, from war zombie to voodoo zombie and viral zombie to consumer and cinema zombie. It's about free and enslaved, philosophical and cannibal, happy and sad zombies. About a life after death that nobody wants to have. About politics, aesthetics and gender theory" (Untot, 2010). Starting from the very first zombie films ("White Zombie", 1932), to the classics ("Otto, or Up with Dead People", 2008 and "Resident Evil", 2002) through numerous Italian interpretations ("Zombies among cannibals", 1980), to little-known movies ("Zombies on Broadway", 1975) or unjustly forgotten representatives of the genre ("Fido", 2006) - they all receive attention on the pages of the monograph. In addition, the queer and gender discourses are given their part - gay zombies seem to have become so popular in recent years. The entries of the third chapter, dealing with sex and gender problematics, reveal that even zombification cannot protect against traditional role clichés regarding the typical representation of man and woman.

The first chapter, entitled "Between cult and cinema: on the history of the zombie film" contains five essays. The title of the second chapter "Fucking dead: zombie and gender" is given in the English language, as opposed to the other two, written in German as all of the texts. The second chapter includes four texts, the third one, "More brain: theories of the zombification", has seven. The last entry, which can be regarded as chapter four, is an interview. All in all, the monograph has 16 essays written by experts in different fields of humanitarian knowledge: media and communication researchers, film and literary scholars, and even a criminal biologist - no other but a renowned Dr. Mark Benecke, well-known in the German 
language world for his fruitful efforts to popularize science with the help of various digital media.

I have listed the essays below to give the reader the overall impression of the topics discussed:

Chapter 1 - BETWEEN CULT AND CINEMA: ON THE HISTORY OF THE ZOMBIE FILM

1. Florian Krautkrämer. A Matter of Life and Death. Life and Death in a Zombie Movie. pp. 19-36.

(The repetition of the expression "life and death" here is due to the fact, that in the first part of the title the author writes it in English, after the bizarre style of contemporary Germans to insert English words wherever possible, while the second time the word combination is in German)

2. Wolf Fuhrmann. A Prisoner from Dahomey. A Colonial Zombie. pp. 37-44.

3. Joachim Schätz. Societies in the films about zombie invasion. pp. 45-64.

4. Frank Neumann. Living with the undead. The Echo of Social Trauma in Zombie Movies. pp. 65-84.

5. Christian Maier. Feast for fans. The Italian zombie movie. pp. 85-98.

\section{Chapter 2 - FUCKING DEAD: ZOMBIE AND GENDER}

1. Michael Fürst. Zombies over the Rainbow. Constructions of gender identity in gay zombie films. pp. 99-120.

2. Alessandro Grilli. A monster squared. Queer reflections on the film "Gay Zombie" by Michael Simon. pp. 121-134.

3. Heike Klippel "Shame and sorrow for the family". Racial and sexual problems in classic zombie films. pp. 135-152.

4. Annekatrin Bock, Holger Isermann, Thomas Knieper. "Adaequamus morte". Gender aspects in "Resident Evil". pp. 153-164.

\section{Chapter 3 - MORE BRAIN: THEORIES OF ZOMBIEFICATION}

1. Serjoscha Wiemer. Parasites and radical de-sublimation in David Cronenberg's "Shivers". pp. 165-180.

2. Michaela Wünsch. Zombies under the influence of the death drive. pp. 181-194.

3. Anke Zechner. Will-less eternal life. The zombie as a figure of excess and exclusion. pp. 195-210.

4. Arno Meteling. The Ornament of the Mass. On Chronotopy and Mediality in the Zombie Film. pp. 211-224.

5. Markus Rautzenberg. Uncanny Valley. A little image theory of zombification. pp. 225-234.

6. Drehli Robnik. Cinema under the sign of the zombies. Undead film characters as mental images in political film theories. pp. 235-258. 
7. Rolf F. Nohr. Viral zombification. "Who's to say we're not all zombies? pp. 259-274.

\section{INTERVIEW}

Interview with Dr. Mark Benecke conducted by Thomas Knieper and Florian Krautkrämer. Psychopaths are nothing but cultivated zombies. pp. 275-281.

As can be seen from the list of contents, the book provides a compilation of high-quality academic essays in German on the phenomenon of zombie films, its varieties and the embedding of "the undead" in philosophy, social science, politics, aesthetics and gender theory. As Mark Kügle, a researcher from Philips University Marburg, remarks in his review "Editors are visibly striving for a differentiated approach to their selected topic. To this end, they allow representatives of a wide variety of academic disciplines to have their say. The reader is then offered sixteen contributions, which present themselves in a strict content concept" (Kügle, 2012, p. 71).

The entries, each comprising about 15-20 text pages, are illustrated by screen images in small format. Each entry has footnotes, providing clarification of the discussed topics and bibliography. Recommended further reading and the original sources can also be found listed after the essays. The texts are on the same academic level, even if in some places the style seems exaggerated (in order to sound more scholastic than I find necessary), e.g.: "The gay undead from "Gay Zombie" thus semiotically refers to the structural mixture of convergence and divergence through an intrinsic time paradox" (Fürst, Krautkrämer \& Wiemer, 2010, p. 136).

I would like to give a short overview of a few entries that I find particularly interesting. The first one is "The Prisoner of Dahomey. A Colonial Zombie" by Wolfgang Fuhrmann, chapter one.

While the American film "White Zombie" shot in 1932 by Victor Halperin is generally considered the founder of the zombie film genre, Fuhrmann in his article points at precursors and variations of the living dead image. German filmgoers can think of Cesare, the somnambulist henchman of Dr. Caligari in Robert Wiene's "The Cabinet of Dr. Caligari", 1920. A year earlier, in the last year of World War I, "The Prisoner of Dahomey", 1918 by Hubert Moest told of a supposed 'avenger' risen from the dead who murderously decimates his enemies. The film was a colonial drama conceived as a lurid inflammatory film designed to turn German audiences against the French enemy in the final months of the war. Behind the production of the film was the German Society for Colonial Cinematography, DEUKO, headquartered in Berlin. The society made it its mission to enforce colonial propaganda during the war with cinematic means. Fuhrmann points out, that since 1904 German viewers could regularly see films from the colonies, With the outbreak of The First World War in August 1914, however, the dream of a German colonial empire came to an abrupt end, and the last from the colonies reached German screens. 
In his article Fuhrmann discusses how colonial films were viewed from in light of the new political situation and how they were integrated into colonial war propaganda.

The film "The Prisoner of Dahomey" tells the story of the German Cameroon planter Burgsdorf, who was imprisoned by the French army at the outbreak of the war and deported to a prison camp in Dahomey (today's Benin). In the camp, Burgsdorf suffers the sadistic excesses of the French camp commandant. Burgsdorf demands fair treatment but is sentenced to flogging with a hippopotamus whip for this "impertinence". On another occasion, Burgsdorf is tortured into unconsciousness, but is rescued by an African woman. To protect him from further torment, she administers a mysterious potion that puts him into a death-like sleep. Burgsdorf is then declared dead and is buried. The African woman uses an antidote to bring him back to life, and now Burgsdorf returns to the camp every night as the living dead, to gradually kill the French.

The film's screenplay was written by Lene Haase, who had made a name for herself as a colonial writer. Through her marriage to a district doctor of the German colony of Cameroon, she got to know details about colonial life, so the story of the farmer Burgsdorf was faintly based on actual experiences. While German colonists were really deported to French camps, Burgsdorf's mysterious death, resurrection, and vendetta were the product of Lene Haase's literary imagination. The author of the article points out, that for the German colonial lobby such a mixture of fact and fiction was not a contradiction, but a proven means of carrying out colonial propaganda among the general public (Fuhrmann, 2010, p.39). He also finds it remarkable that the screenplay constructs an alliance of African voodoo culture and German resistance against French enemies. Contrary to colonial missionary ideology, which viewed Africans as uneducated children who must be raised to a higher, Christian level of civilization, in "Prisoner of Dahomey" the Other, foreign knowledge is decisive for Burgsdorf's successful campaign of revenge.

The work by Alessandro Grilli "A monster squared. Queer reflections on the film "Gay Zombie" does not discuss the morbid question of whether a zombie can be straight/gay and how one makes love to a (gay) zombie. It deals with much deeper and more important problems of power and control that a society manifests over an individual while manipulating their love and their sexual lives. Citing Butler's theory of gender as a script to be performatively actualized, Grilli speaks of two strategies of repressive inclusion that can be seen in the film "Gay Zombie". The zombie's deviant appearance is disguised under a surface of make-up. This depicts the very "normalcy", the objective of assimilation, to be nothing but a disguise to be assumed at will. The second strategy of repressive inclusion is seen in the conformity of the gay community discourse to a politically correct form of expression: "The refusal to call things by their name («DWAYNE You know... you have... what we call "problematic skin", 10:05) is the first step of a blunting of perception which ends in the impossibility to recognize the peculiarity and irreducibility of the individual as such. Far from accepting the other, political correct- 
ness makes it impossible to perceive its otherness, and ultimately its very existence" (Grilli, 2012, p. 58).

In the end of the film a psychotherapist that treats the protagonist cold-bloodedly shots his friend the zombie. When the boy starts to protest, she insists that it is done for his own good, as his relations with the zombie were improper and dangerous. She manages to suppress the boy's will with her doctor's authority to such extent that he not only agrees with the murder, but also thanks her for that - at which point the doctor reveals her own hand with the traces of decay on it. She turns out to be a zombie herself, thus the murder of the gay zombie had in fact nothing to do with propriety and safety - it was sheer manifestation of power over an individual for the power's sake. This allows Grilli to conclude that the purpose of society is to discourage all forms of centrifugal attachment. Just as Winston, the character from the famous anti-utopian novel "1984" manages to escape the torture by offering his beloved Julia as a replacement for himself, so the boy in "Gay Zombie" accepts the therapist's reasons for murder and even thanks her. In both cases the characters who have been subjected to power manipulations were made to abjure their deepest desires and affections and thus deprived of their individuality (Grilli, 2010).

An interview with a forensic scientist Mark Beneke is the last chapter of the reviewed volume. From a scientific perspective and against the background of years of experience in dealing with real corpses, Doctor Benecke provides insight into the processes of dead body decomposition that he believes lies behind the zombie (and vampire) myths. In his own classification of myth-related bodies, a zombie corpse differs from a vampire corpse in the absence of 'disgusting' signs of decay. A prerequisite for the formation of a zombie corpse is rapid desiccation. This happens when it is very hot and there is also a light wind blowing consistently. The adult blowflies then do not lay their eggs in the eyes, which preserves them. Due to the drying process, the eyes become slightly milky. The body itself dries out. When asked about Voodoo zombies, Dr. Benecke points out that the effect of poison on the human brain is different than described in zombie stories, so a voodoo priests operated more with hypnosis that works because the victims believe in the curse. With the poisons alone, they could not have created working slaves.

When shown photos of zombie make-up from various films, Dr. Benecke commented on plausibility of decomposition processes reflected in make-up works. Thus, images from Romero's "Night of the living dead" didn't receive the approval of the famous forensic biologist: since these zombies were bitten by other zombies while still human, the wounds on their bodies should be vital injuries. But the detachment of upper layers of skin is a clear sign of decay. On some other photograph he pointed at the signs of inflammation that can be seen only on living people but never on dead bodies. Further Benecke speaks about rudimentary egoperception that zombies must still have, the mechanism that exists in animals with rope ladder nervous system and without central nervous system. Zombies, too, 
must have at least a diffuse form of self-awareness (Fürst, Krautkrämer \& Wiemer, 2010, pp. 275-281).

On his own site Dr. Benecke published a short zombie-related article discussing the physiological aspects of death by zombie bite - as well as physiological processes that occur while a zombie is being destroyed. Comic as it is, the description is quite scientific and is in correspondence with popular matter-offact approach to zombie apocalypses. From his German-language article, entitled "Zombie death for the beginners" we learn that beheading a zombie technically should not be an effective way of destroying it. While dismemberment is a classical way to kill someone, for it means "injuries incompatible with life", it is well known that dismembered zombies can be successfully reassembled or even do so themselves. Various films show that severing the head is what causes zombies the most trouble. If this is true, then perhaps the undead, decaying, infected tissue also needs a control unit, which is apparently located somewhere in the head. So, unlike "healthy" humans, the death of zombies after head severances would simply be the collapse of the last remnant of their physical organization (Benecke, 2016).

Returning to the interview for "The Undead" publishers: Mark Benecke is asked at the end what a zombie is from his point of view, whereas he surprises the readers by the answer that zombies are "People who completely don't care about the environment and are just libidinous. In a way, they are sociopathic psychopaths.... successful psychopaths would actually be cultivated zombies" (Fürst, Krautkrämer \& Wiemer, 2010, p.281).

The monograph is definitely worth reading. It can attract interest of academic circles as well as fans of horror films, virus films, apocalypses films and the lovers of all things zombie. Quoting Mark Kügle again, "No matter from which perspective film-historical, film-critical, media-aesthetic, media studies, cultural studies, gender-theoretical, forensic - the phenomenon of zombie is approached, "The Undead" conveys the discreet charm of a work that was explicitly written by fans for fans everywhere" (Kügle, 2012, p. 75).

I find it strange that the monograph with all its contents still hasn't found a translator into the English language and a publisher willing to host such a translation. For, though German is presumably the second European language, it still limits the access to the research that the papers written in the English language enjoy. Fully recognizing the importance of such monograph for the German scholarly world, I would hope for "The Undead - Zombie Film Theory" to claim the worldwide recognition.

\section{References / Список литературы}

Benecke, M. (2016). The Little Doomsday Guide, Part 2: Zombie Death for Beginners. Retrieved from Tor Online website: http://www.tor-online.de/index.php?id=1013 (In German)

Fuhrmann, W. (2010). A Prisoner from Dahomey. A Colonial Zombie. In Untot-Zombie Film Theory (pp. 37-44). München: Belleville. (In German). 
Fürst, M., Krautkrämer, F., \& Wiemer, S. (2010). The Undead-Zombie Film Theory. Münich: Belleville. (In German).

Grilli, A. (2010). A Monster squared. Queer reflections on the film 'Gay Zombie' by Michael Simon. In Untot-Zombie Film Theory (pp. 121-134). München: Belleville. (In German).

Grilli, A. (2012). Queering the Dead: Dead Zombies in the Dark Room. In Queer Crossings: Theories, Bodies, Texts (pp. 47-62). Milano-Udine: Mimesis Edizioni.

Kügle, M. (2012). Michael Fürst, Florian Krautkrämer, Serjoscha Wiemer (Hg.): Untot - Zombie Film Theorie [Application/pdf]. Medienwissenschaft, (1), 71-75. (In German). Doi: 10.17192/EP2012.1.110

The Undead-Zombie Film Theory. (2010). Retrieved from http://www.belleville-verlag.de/scripts/buch.php?ID=313 (In German) 